\title{
The Impact of Economic Capital, Social Capital and Cultural Capital: Chinese Families' Access to Educational Resources
}

\author{
Jingbo Fan \\ School of Public Administration, University of International Business and Economics, Beijing, China \\ Email: jfa2014@126.com
}

Received 23 June 2014; revised 26 July 2014; accepted 18 August 2014

Copyright @ 2014 by author and Scientific Research Publishing Inc. This work is licensed under the Creative Commons Attribution International License (CC BY). http://creativecommons.org/licenses/by/4.0/

(c) (i) Open Access

\begin{abstract}
Family background can influence an individual's access to educational resources. Specifically, an advantaged family background can promote an individual's access to educational resources. This study constructs a model to analyze the impact of the economic, social and cultural capital of Chinese families on their children's education. The results show that all three types of capital have significant effects on individual education but a family's cultural capital has the strongest effect. Furthermore, the father's background influences a child's education more than the mother's for all three types of capital. The present study affirms the importance of the resource-centered conception of economic, social and cultural capital that significantly influences inequality as a predominant issue in China.
\end{abstract}

\section{Keywords}

Educational Resources, Family Background, Economic Capital, Social Capital, Cultural Capital

\section{Introduction}

The increasing importance of education for China's economic and social development has been demonstrated. In the competition for educational opportunities, access to educational resources depends not only on the competitor's innate talents and efforts but also on the competitor's family background. In each social class, families' differential access to economic, social and cultural resources inevitably has an impact on children's access to educational resources. Increasingly, high-level and high-quality educational resources are available only to families with a higher social status or wealthier economic background. China is currently in a transitional stage, and social stratification is beginning to play an even more significant role in its citizens' lives. Family background therefore is beginning to have a greater effect on access to educational resources. 
High-quality educational resources are currently still scarce in China. The gap between rich and poor is increasing, and the fair allocation of resources is garnering increased attention. In China, students are generally unable to finance their education by obtaining part-time jobs, and a family's economic background therefore influences the type of education received. After completing nine years of compulsory education, any further education must be financed by a student's parents. However, the quality of resources available through the compulsory education system also varies. Family factors therefore affect educational input and output, and high-quality educational resources are increasingly monopolized by families with good economic capital, social capital and cultural capital, to use the categories described by Bourdieu.

A family's economic capital is the capital that can be immediately and directly converted into money and that may be institutionalized in the form of property rights; it represents the economic resources owned by a family. Economically advantaged families can provide children with material security and with educational resources of a higher quality.

A family's social capital is the aggregate of the actual or potential resources available to them through a durable network of more or less institutionalized relationships based on mutual acquaintance and recognition. A family's social capital may be represented by the status of the parents' workplace or job and can influence the offspring's education (Lauglo, 2011).

Abundant "Guanxi” and high social status facilitates access to high-quality educational resources. "Guanxi” is a link established between people for the purpose of personal gain. Moreover, a family's cultural capital can be inherited by subsequent generations. Bourdieu (1973) first used the term cultural capital in his "Cultural Reproduction and Social Reproduction”. Cultural capital is convertible, under certain conditions, into economic capital and can be institutionalized in the form of educational qualifications. Cultural capital exists in three forms: in the embodied state of the mind and body, which is communicated unconsciously and internalized through and during family socialization processes (Symeou, 2007); in the objectified state of cultural goods such as pictures, books, etc.; and in the institutionalized state, a form of objectification exemplified by educational qualifications. Institutionalization confers novel properties on the cultural capital which is presumed to guarantee. Bourdieu's theory of cultural reproduction proposes that the reproduction of cultural capital is closely related a family's education, rendering the family the locus of cultural capital production. Siblings inherit their parents' cultural capital through unconscious imitation and eventually come to embody it. Parents' education may affect the educational views, modes and choices of their children and may also affect children's learning attitudes and academic goals. Parents who have received higher degrees and systematic education and training can usually create a good cultural atmosphere and cultural environment for their children. Therefore, parents with higher educational levels tend to have children with higher educational levels (Bourdieu, 1986).

Education equity has been a long-standing goal of human societies. Education promotes intergenerational mobility. Therefore, ensuring the fairness of educational opportunities is crucial for achieving social equity. Lack of educational equality reduces social mobility, widens the wealth gap, and may also make this gap permanent. As family factors begin to limit an individual's access to educational resources, society's conditions become increasingly unfavorable to the principles of educational equity. Therefore, it is crucial to determine the influence of family factors on children's access to educational resources and to analyze educational equity issues thoroughly and systematically.

\section{Literature Review}

Research about family factors and their influence on children's access to educational resources and educational equity has been conducted from various perspectives. Each family possesses different economic, social and cultural resources. These differences are reflected in their children's educational opportunities. Family background factors can explain 25\% of the differences in the educational resources children obtain (Van Eijck, 1996). By comparing the differences in the educational opportunities obtained by the children of wealthy families and poor families, Blanden and Gregg (2004), Tieben et al. (2010) and Gerardi (2011) found that children of wealthy families have greater access to educational resources. Denzler (2011), Wang (2012) and Yang (2012) found that children whose parents have higher social status education levels and incomes have higher academic goals and more opportunities to receive higher education. Other studies, such as those by Waters (2006), Dika and Singh (2002) and Zhou and Kim (2006), have confirmed these results.

Family background affects children's learning attitudes, academic achievement and academic goals. According to Bourdieu's (1977) cultural reproduction theory, students with better family backgrounds inherit most of 
their socially valuable cultural patterns from their parents. This cultural capital allows them to achieve better academic performance. Family size, structure, atmosphere and other factors also affect children's performance in school (Onatsu-Arvilommi, 1997). In addition, parents' education has an intergenerational inheritance effect. Their education level significantly influences their children's access to educational resources, which is reflected in their cultural reproduction capabilities (Checchi, 2006; Krishnan, 1996; Currie, 2003; Fang \& Feng, 2008). Family background, family income, and hometown location have also been found to affect the mental health of college students. The influence of family background on access to educational resources can be found in each stage of a child's education. Chinese families have always attached importance to the education of their children, a tradition that increases the influence of family background on education. Families with better capital can help their children make better educational choices, even during the basic education stage (Fang, 2011). Class differences exert an influence even in the compulsory education stage. Tao and Yang (2007) and Albert (2000) studied the relationship between family background and high school education and found that family background strongly influences students' ability to enter China's "key” middle schools. In both urban and rural areas, stratification of high school students is obvious. Upper class children are more likely to gain entrance to a key middle school, while lower class children are usually funneled into ordinary schools.

Since the implementation of the university tuition charge system in the 1990s, China's higher education charges have constantly increased, increasing the influence of family background on access to higher education. Many students admitted to universities do not complete their studies because of their family's economic conditions. Following the CPC Central Committee's and the State Council's 1999 decision to broaden education reform and promote educational quality, enrollment in higher education expanded and became more popular. This expansion prompted discussion of how to distribute higher education resources fairly and address the differences in the quality of educational resources. Zhang (2010), Wei et al. (2009), Tan and Xie (2011), Shen and Yan (2006) and Yang (2011) studied the influence of family background on students' higher education opportunities and found that students with a good family background had more opportunities to pursue higher education. The results showed that the higher the parents' education level and class status, the greater the children's opportunity to receive higher education. Clearly, the expansion of higher education enrollment has strengthened the influence of family background, which will increase inequality in Chinese society. Realizing this, education policymakers have attempted to narrow the education gap between class and access to higher education. In addition to affecting the amount of higher education received, family background also affects the quality of education children receive. The children of parents with higher degrees are more likely to receive a higher quality of higher education (Yang, 2012; Hou et al., 2008; Wen, 2005).

In China's current stage of development, establishing education equality is important. It not only establishes social justice but also promotes social fairness. Research on the effect of family background on access to educational resources is therefore of singular importance. The literature review demonstrates that research about the impact of family factors on human capital has revealed significant findings, especially the studies detailing the influence of family factors on access to educational resources. However, this field of research has left some theoretical and practical problems under-studied. These problems are uniquely urgent in the Chinese context. The influence of family factors on access to educational resources has been conducted from multiple perspectives, but the existing studies focus primarily on a particular stage of education and rarely provide an analysis applicable to all stages of education. Furthermore, the existing research primarily investigates whether family factors affect children's academic achievement and does not provide information about the level of influence family factors play in access to educational opportunities.

This article studies human capital from the perspective of educational equity and conducts a systematic analysis of the impact of a family's economic, social and cultural capital on their children's educational resources. The findings of the present study contribute to a better understanding of the impact of Chinese families' economic, social and cultural capital on individual education outcome.

\section{Data ${ }^{1}$ and Sample Description}

This research used the data collected from the CGSS (China General Social Survey) in 2008. The CGSS re-

\footnotetext{
${ }^{1}$ Data analyzed in this study were collected by the research project “China General Social Survey (CGSS)”sponsored by the China Social Science Foundation. This research project was carried out by Department of Sociology, Renmin University of China \& Social Science Division, Hong Kong Science and Technology University, and directed by Dr. Li Lulu \& Dr. Bian Yanjie. The author appreciates the assistance in providing data by the institute and individuals aforementioned. The views expressed herein are the authors' own.
} 
cruited samples from 28 provinces, autonomous regions and directly controlled municipalities. The survey sampled 125 counties (districts), including 500 streets/towns in approximately 1000 neighborhoods/villages. The survey used a four-phase stratified sampling strategy with unequal probabilities. In the first phase, the districts (the urban and suburban districts of the prefecture-level cities, capital cities of provinces and directly controlled municipalities) were the primary units sampled. In the second phase, the streets and towns were sampled. In the third phase, the neighborhoods and villages were the tertiary units of sampling. In the fourth phase, the families were the final sample units; one person per family was chosen for the data collection. Four secondary units (streets/towns) were sampled from each primary unit (districts/counties), two tertiary units (neighborhoods/ villages) from each secondary unit and 10 quaternary units from each tertiary unit ${ }^{2}$.

The 2008 CGSS data consists of 6000 samples. Of these, 2892 were male and 3108 female, comprising 48.2\% and $51.8 \%$ of the sample, respectively. There were also 3982 urban samples and 2018 rural samples, comprising $66.4 \%$ and $33.6 \%$ of the sample, respectively.

The 2008 CGSS also collected family background data. Part of the survey asked about the family's economic capital, such as "the number of siblings" in the family. Another section surveyed the family's economic and social capital, such as the administrative ranking of the interviewee's residence at the age of 14 , whether or not the parents were communist, the parents' registered permanent residence, the parents' employment status and the nature of the parents' workplace (organization/company) when the interviewee was 14 . The survey also explored the highest degree of education achieved by the parents, which can reflect the family's cultural capital.

The "the highest degree of education" variable in the CGSS data represents an individual's access to educational resources. This variable is divided into 14 levels: $1=$ no educational background; $2=$ private school; $3=$ primary school; 4 = middle school; 5 = vocational high school; 6 = high school; 7 = vocational school; 8 = technical school; 9 = technical college (adult higher education); 10 = technical college (regular higher education); 11 $=$ undergraduate college (adult higher education); 12 = undergraduate college (regular higher education); $13=$ graduate school and higher education degrees; $14=$ other education degrees. These 14 education levels were combined into seven types: 1 = illiteracy ${ }^{3} ; 2=$ primary school; $3=$ middle school; $4=$ high school ${ }^{4} ; 5=$ technical school ${ }^{5} ; 6$ = undergraduate college ${ }^{6}$; and 7 = graduate school. The sizes of the illiteracy, primary school, middle school, high school, technical school, undergraduate college and graduate school samples were 503, 1449, 1760, 1374, 496, 380 and 28, respectively. They comprised 8.4\%, 24.2\%, 29.3\%, 22.9\%, 8.3\%, 6.3\% and 0.5\% of the sample, respectively. Missing data comprised ten samples, or $0.2 \%$ of the data.

\section{Study Variables and Models}

This research constructs an analytical model to study the influence of economic, social and cultural capital on an individual's access to educational resources. The model uses categorical regression with optimal scaling. Because the number of variables in the database that reflect family background is limited, the variables selected and the model design are constrained by the information available in the database. The dependent variable is the degree of education achieved by the individual; the independent variables are the families' economic, social, and cultural capital. Because the variables that reflect the families' economic and social capital cannot be clearly distinguished, they are combined and represented by the "Ces" variable; "Cc" denotes the family's cultural capital. The age and sex factors were expected to influence individual education. Therefore, the two factors are introduced into the model as controlled variables. A description of the independent variables is provided in Table 1.

Three models were constructed to analyze how families' economic, social and cultural capital respectively and comprehensively influence access to educational resources.

First, family economic and social capital are integrated with the regression equation to build Model 1, which analyzes how these two variables respectively influence an individual's degree of education:

$$
\mathrm{Edu}=\mathrm{Age}+\mathrm{Sex}+\sum_{i=1}^{m} \operatorname{Ces}_{i} \quad(i=1, \ldots, m)
$$

\footnotetext{
${ }^{2}$ See China Survey and Data Center of Renmin University of China, China General Social Survey (CGSS) Project. China General Social Survey Report (2003-2008) [M]. Beijing: China Social Press, 2009, 1-8.

${ }^{3}$ Includes no educational background and private school.

${ }^{4}$ Includes vocational high school, high school, vocational school and technical school.

${ }^{5}$ Includes technical college (adult higher education) and technical college (regular higher education).

${ }^{6}$ Includes undergraduate college (adult higher education) and undergraduate college (regular higher education).
} 
Table 1. Description of the independent variables.

\begin{tabular}{|c|c|c|c|}
\hline Type & $\begin{array}{l}\text { Independent } \\
\text { variable }\end{array}$ & Meaning & Value \\
\hline \multirow{2}{*}{ Controlled variable } & Age & Age & \\
\hline & Sex & Sex & 1 = female, 2 = male \\
\hline \multirow{12}{*}{$\begin{array}{l}\text { Family's economic } \\
\text { and social capital } \\
\text { (Ces) }\end{array}$} & Res & $\begin{array}{l}\text { The interviewee's main } \\
\text { residence at the age of } 14\end{array}$ & $\begin{array}{c}1 \text { = village/town, } 2 \text { = county, } 3=\text { prefecture-level city/provincial-level } \\
\text { municipality (including Chongqing), } 4=\text { Beijing/Tianjin/Shanghai, } \\
5 \text { = overseas, } 6 \text { = other }\end{array}$ \\
\hline & Sib & The number of siblings & \\
\hline & Comf & Father's political status & $1=$ non-communist, $2=$ communist \\
\hline & Regf & $\begin{array}{l}\text { Father's registered } \\
\text { permanent residence }\end{array}$ & $\begin{array}{c}1 \text { = other, } 2 \text { = rural registered permanent residence, } 3=\text { town registered } \\
\text { permanent residence, } 4=\text { county-level city registered permanent } \\
\text { residence, } 5 \text { = prefecture-level city registered permanent residence, } \\
6=\text { provincial capital registered permanent residence, } \\
7 \text { = directly-controlled municipality registered permanent residence }\end{array}$ \\
\hline & Empf & $\begin{array}{l}\text { Father's employment } \\
\text { status at the age of } 14\end{array}$ & $\begin{array}{l}1=\text { other, } 2=\text { retirement, } 3=\text { temporary employment, } \\
4=\text { part-time employment, } 5=\text { full-time employment }\end{array}$ \\
\hline & Ownf & $\begin{array}{l}\text { The ownership of the } \\
\text { father's work } \\
\text { organization/company } \\
\text { at the age of } 14\end{array}$ & $\begin{array}{c}1 \text { = other, } 2 \text { = sino-foreign joint venture, } 3 \text { = foreign-owned enterprise, } \\
4=\text { Taiwan, Hong Kong and Macao capital investment, } 5 \text { = private } \\
\text { ownership, } 6 \text { = collective ownership, } 7 \text { = state ownership }\end{array}$ \\
\hline & Orgf & $\begin{array}{l}\text { The nature of the father's } \\
\text { work organization/company } \\
\text { at the age of } 14\end{array}$ & $\begin{array}{c}1=\text { other, } 2 \text { = non-organization/self-employed/self-managed } \\
\text { (cooperative) enterprise, } 3=\text { social organization, } 4=\text { institution, } \\
5=\text { enterprise, } 6 \text { = office of the communist party and the government }\end{array}$ \\
\hline & Comm & Mother's political status & $1=$ non-communist, $2=$ communist \\
\hline & Regfm & $\begin{array}{l}\text { Mother's registered } \\
\text { permanent residence }\end{array}$ & $\begin{array}{c}1 \text { = other, } 2 \text { = rural registered permanent residence, } 3=\text { town registered } \\
\text { permanent residence, } 4 \text { = county-level city registered permanent } \\
\text { residence, } 5 \text { = prefecture-level city registered permanent residence, } \\
6=\text { provincial capital registered permanent residence, } \\
7 \text { = directly-controlled municipality registered permanent residence }\end{array}$ \\
\hline & Empm & $\begin{array}{l}\text { Mother's employment } \\
\text { status at the age of } 14\end{array}$ & $\begin{aligned} 1=\text { other, } 2 \text { = retirement, } 3=\text { temporary employment, } 4=\text { part-time } \\
\text { employment, } 5 \text { = full-time employment }\end{aligned}$ \\
\hline & Ownm & $\begin{array}{l}\text { The ownership of the } \\
\text { mother's work } \\
\text { organization/company } \\
\text { at the age of } 14\end{array}$ & $\begin{array}{c}1 \text { = other, } 2 \text { = sino-foreign joint venture, } 3 \text { = foreign-owned enterprise, } \\
4 \text { = Taiwan, Hong Kong and Macao capital investment, } 5 \text { = private } \\
\text { ownership, } 6 \text { = collective ownership, } 7 \text { = state ownership }\end{array}$ \\
\hline & Orgm & $\begin{array}{l}\text { The nature of the } \\
\text { mother's work } \\
\text { organization/company } \\
\text { at the age of } 14\end{array}$ & $\begin{array}{c}1 \text { = other, } 2 \text { = non-organization/self-employment/self-management } \\
\text { (cooperative) enterprise, } 3=\text { social organization, } 4=\text { institution, } \\
5 \text { = enterprise, } 6 \text { = office of the Communist Party and the Government }\end{array}$ \\
\hline \multirow{2}{*}{$\begin{array}{l}\text { Family's cultural } \\
\text { capital (Cc) }\end{array}$} & Eduf & $\begin{array}{l}\text { Father's highest education } \\
\text { degree }\end{array}$ & $\begin{array}{c}1 \text { = illiteracy, } 2 \text { = primary school, } 3=\text { middle school, } 4=\text { high school, } \\
5=\text { technical school, } 6=\text { undergraduate college, } \\
7 \text { = graduate school and higher education }\end{array}$ \\
\hline & Edum & $\begin{array}{l}\text { Mother's highest education } \\
\text { degree }\end{array}$ & $\begin{array}{c}1=\text { illiteracy, } 2 \text { = primary school, } 3=\text { middle school, } \\
4=\text { high school, } 5=\text { technical school, } 6=\text { undergraduate college, } \\
7=\text { graduate school and higher education }\end{array}$ \\
\hline
\end{tabular}

In the above equation, $m$ is the number of variables used to define the economic and social capital of the families.

Second, family cultural capital is introduced into the regression equation to create Model 2, which analyzes the influence of cultural capital on an individual's degree of education:

$$
\mathrm{Edu}=\mathrm{Age}+\mathrm{Sex}+\sum_{j=1}^{n} \mathrm{Cc}_{j} \quad(j=1, \ldots, n)
$$


In the above equation, $n$ is the number of variables used to determine a family's cultural capital.

Finally, the families' economic, social and cultural capital are introduced into the regression equation simultaneously to create Model 3, which analyzes how the three types of capital, individually and as a whole, influence individual education.

$$
\mathrm{Edu}=\mathrm{Age}+\mathrm{Sex}+\sum_{i=1}^{m} \operatorname{Ces}_{i}+\sum_{j=1}^{n} \mathrm{Cc}_{j} \quad(i=1, \ldots, m ; j=1, \ldots, n)
$$

\section{Results}

The models use categorical regression to analyze the data. The optimal scaling level of the independent variables is the spline ordinal, degree $=2$, interior knots $=2$. The variables with missing values are processed using the command, "Exclude objects with missing values on this variable".

\subsection{Regression Results for Model 1}

The regression results for Model 1 show that a family’s economic and social capital have a significant impact on an individual's degree of education. The adjusted $\mathrm{R}^{2}$ is 0.287 and the Sig value of the F test is below 0.01 , indicating that sex, age, and the family's economic and social capital explain $28.7 \%$ of the dependent variable's total variance. With the exception of "the interviewee's main residence at the age of 14", “father's employment status at the age of 14", "mother's registered permanent residence” and "the ownership of the mother's work organization/company at the age of 14", all of the variables show significance. The results are presented in Table 2 and Table 3.

Table 2. Comparison of the regression results for the three models.

\begin{tabular}{|c|c|c|c|}
\hline & Model 1 & Model 2 & Model 3 \\
\hline \multirow{16}{*}{ Independent variables } & Age & Age & Age \\
\hline & Sex & Sex & Sex \\
\hline & Res & & Res \\
\hline & Sib & & Sib \\
\hline & Comf & & Comf \\
\hline & Regf & & Regf \\
\hline & Empf & & Empf \\
\hline & Ownf & & Ownf \\
\hline & Orgf & & Orgf \\
\hline & Comm & & Comm \\
\hline & Regfm & & Regfm \\
\hline & Empm & & Empm \\
\hline & Ownm & & Ownm \\
\hline & Orgm & & Orgm \\
\hline & & Eduf & Eduf \\
\hline & & Edum & Edum \\
\hline Adjusted $\mathrm{R}^{2}$ & 0.287 & 0.338 & 0.344 \\
\hline $\mathrm{F}$ & 20.438 & 250.760 & 22.533 \\
\hline Sig. & 0.000 & 0.000 & 0.000 \\
\hline
\end{tabular}


Table 3. Detailed regression results for Model 3.

\begin{tabular}{|c|c|c|c|c|c|}
\hline \multirow{2}{*}{$\begin{array}{l}\text { Independent } \\
\text { variable }\end{array}$} & \multicolumn{2}{|c|}{ Standardized coefficients } & \multirow{2}{*}{ Importance } & \multicolumn{2}{|c|}{ Tolerance } \\
\hline & Beta & Std. error & & After transformation & Before transformation \\
\hline Age & $-0.263^{* *}$ & 0.035 & 0.307 & 0.444 & 0.443 \\
\hline Sex & -0.016 & 0.024 & 0.000 & 0.980 & 0.976 \\
\hline Res & -0.038 & 0.030 & -0.005 & 0.603 & 0.530 \\
\hline Sib & $-0.133^{* *}$ & 0.031 & 0.140 & 0.591 & 0.528 \\
\hline Comf & 0.046 & 0.027 & 0.019 & 0.753 & 0.779 \\
\hline Regf & $0.175^{* *}$ & 0.041 & 0.062 & 0.335 & 0.169 \\
\hline Empf & -0.014 & 0.029 & -0.004 & 0.637 & 0.541 \\
\hline Ownf & $0.075^{*}$ & 0.031 & 0.022 & 0.584 & 0.475 \\
\hline Orgf & $0.062^{* *}$ & 0.026 & 0.021 & 0.793 & 0.391 \\
\hline Comm & $0.070^{* *}$ & 0.026 & 0.029 & 0.809 & 0.819 \\
\hline Regfm & -0.039 & 0.042 & -0.009 & 0.315 & 0.164 \\
\hline Empm & $0.061^{*}$ & 0.031 & 0.014 & 0.586 & 0.486 \\
\hline Ownm & 0.032 & 0.033 & 0.009 & 0.520 & 0.492 \\
\hline Orgm & -0.048 & 0.034 & -0.008 & 0.467 & 0.389 \\
\hline Eduf & $0.174^{* *}$ & 0.032 & 0.223 & 0.544 & 0.511 \\
\hline Edum & $0.148^{* *}$ & 0.031 & 0.179 & 0.586 & 0.469 \\
\hline
\end{tabular}

Notes: "Shows significance greater than $0.05 ;{ }^{* *}$ Shows significance greater than 0.01 .

\subsection{Regression Results for Model 2}

Model 2 analyzes individual education using optimal scaling. The regression results show that the adjusted $\mathrm{R}^{2}$ is 0.338 and the Sig value of the F test is below 0.01, indicating that sex, age and family cultural capital explain $33.8 \%$ of the total variance of the dependent variable. This result is larger than the $28.7 \%$ explained variance found using Model 1, indicating that a family's cultural capital, (i.e., the parents' educational background) has a greater impact on individual access to educational resources than economic or social capital. The regression results show that the educational backgrounds of both the father and mother have a significant impact on the dependent variable. Both are positive values, indicating that individual education is significantly higher when parents are more highly educated.

\subsection{Regression Results for Model 3}

When family economic, social and cultural capitals are introduced into the model simultaneously, as in Model 3, the regression results yield an adjusted $\mathrm{R}^{2}$ of 0.344 , indicating that Model 3 can explain $34.4 \%$ of the total variance of the dependent variable. This value is lager than the $28.7 \%$ found by Model 1 and the $33.8 \%$ by Model 2. The adjusted $\mathrm{R}^{2}$ of 0.344 indicates that $34.4 \%$ of the variance in the transformed preference rankings was explained by regression on the optimal transformed predictors. The remaining unobserved variables include such factors as personal aptitude and educational policies.

Furthermore, the coefficients of the Sig values indicate that the variables, including "age", "the interviewee's main residence at the age of 14", "father's political status", "father's employment status at the age of 14", "mother's registered permanent residence", "the ownership of the mother's work organization/company at the age of 14" and "the nature of the mother's work organization/company at the age of 14", did not contribute significantly to the regression equation. The remaining variables did significantly contribute to the regression equation. An $\mathrm{F}$ test determines whether the omission of a predictor variable from the model when all other predictors 
are present significantly worsens the predictive capabilities of the model.

The estimated values of the coefficients show that the "age" coefficient is negative but has the largest absolute value, indicating that when other variables are controlled, the older interviewees received less education. This result shows the tremendous development of Chinese education during the recent decades. Among all of the variables, including the family economic, social and cultural capital variables, those with the higher absolute-value coefficients were "father's registered permanent residence", "father's highest education degree", "mother's highest education degree" and "the number of siblings". When the father's registered permanent residence was more advantageous and the parents' were more highly educated, the interviewees generally had higher degrees of education. However, the more siblings the interviewees had, the less education they received. The coefficient value of "father's highest degree" variable was 0.174, indicating that an increase of one standard deviation in "father's highest degree" yields an increase of 0.174 in the standard deviation of the predicted preference ranking.

All of the tolerance measures were not low. This result indicates that none of the predictors were significantly predicted by the other predictors, and multi-collinearity was not present.

The zero-order correlation is the correlation between the transformed predictor and the transformed response. The largest correlation, for "father's highest education degree", was 0.462 . The squared partial correlation represents the ratio of the explained variance to the residual variance of the response remaining after the effect of the other variables has been removed. After removing the effects of the other variables, "age" explained $(-0.214)^{2}=0.046$ of the variation in the preference rankings. "Father's highest education degree" and "mother's highest education degree" also explained a large portion of the variance when the effects of the other variables were removed. The correlation between the response and the residuals from regressing a predictor on the other predictors is called a partial correlation. When the effects of the other variables were removed, the remaining residual of "father's highest education degree" explained $0.128^{2}=0.016$ of the variation in preference rankings.

The importance values of "age”, "father's highest education degree”, "mother’s highest education degree” and "the number of siblings" were the greatest among the variables, indicating that these four variables made larger contributions to the regression equations. The importance value of "age" was 0.307 , indicating that age makes $30.7 \%$ of the contributions to the regression equation. The importance values of "father's highest education degree" and "mother's highest education degree" were 0.223 and 0.179 , respectively, indicating that they collectively comprised $40.2 \%$ of the contributions to the regression equation. These results show that a family's cultural capital significantly influences an individual's access to educational resources. The contribution of "sex" to the models was insignificant, indicating that when the other variables were controlled, males and females experienced similar access to educational resources at all educational levels. "The number of siblings" in the family comprised $30.7 \%$ of the contributions to the models, indicating that this variable can greatly influence an individual's access to educational resources. Other variables accounted for $15.1 \%$ of the contributions to the models.

The results from the parents' contributions showed that the economic and social capital of the father accounted for $12 \%$ of the contributions to the models, and his cultural capital comprised $22.3 \%$, yielding a total contribution of $34.3 \%$. The economic and social capital of the mother accounted for only $3.5 \%$ of contributions to the models, and her cultural capital contributed $17.9 \%$, yielding a total contribution of $21.4 \%$. These results indicate that the father has a greater influence on his offspring's educational attainment than the mother with respect to the family economic and social capital and family cultural capital. The father therefore greatly influences his offspring's access to educational resources.

\section{Conclusion}

In summary, the results show that family background factors have a significant impact on children's access to educational resources. In addition, a family's economic, social and cultural capital, respectively, each significantly affected individuals' education, but family cultural capital had the greatest influence. An analysis of each variable revealed that "father's registered permanent residence", "father's highest education degree" and "mother's highest education degree" all promoted their children's education. However, "the number of siblings" was negatively correlated with the individual's educational attainment. Furthermore, in all aspects of family background, the father's degree of influence was greater than the mother's.

\section{Further Analysis}

It is important to study the effects of family background on access to educational resources in China, especially 
in light of the changes China is now facing. Currently, educational resources are scarce, the gap between rich and poor is widening, the role of social stratification is increasing and high-quality educational resources are being monopolized by wealthy families. Families will take advantage of opportunities to provide excellent educational conditions for their children. The greater the role played by family background, the more difficult it will become to achieve equitable educational resources' distribution.

Currently, China is in a special historical transition phase. Social stratification is beginning to play a larger role in individuals' lives, and fairness is becoming a concern. The government proposed a development strategy aimed at "promoting social equity, striving to create a fair social environment, and ensuring people's right of equal participation and equitable development" in the 18th Chinese Communist Party National Congress. A person's success depends largely on his own level of human capital, especially the human capital improvement obtained through education. This perspective suggests that education promotes intergenerational mobility. Therefore, ensuring the fairness of educational opportunities is important for achieving social justice. In the National Long-Term Education Reform and Development Plan (2010-2012), the government proposed an education policy, stating, "The promotion of equity is a national basic education policy. Educational fairness is an important foundation for social justice. Equity's key is Equal Opportunity; its basic requirement is to safeguard citizens' right to receive education. The focus is to promote the balanced development of compulsory education and support impoverished groups. Its basic measures are the rational allocation of educational resources and the narrowing of the education gap.” If family factors, especially economic and social capital, continue to limit individuals' access to educational resources, the principle of fairness will be increasingly violated.

The government should take measures to weaken the role of family background in educational resource allocation. The government should increase education funding as soon as possible until it accounts for $4 \%$ of the $\mathrm{GDP}^{7}$. If the public's financial investment in education increased, it is possible the effect of family background would be reduced. The government and universities should also increase the funding available to poor students, improve education's ability to promote intergenerational mobility and prevent the intergenerational transmission of poverty.

\section{Acknowledgements}

This study was supported by grants from the China National Social Science Foundation [13CGL120, 13BZX024], the Ministry of Education, China [12YJA7200032], and Tsinghua University [Award \#20121088029, Award \#20119990010].

\section{References}

Albert, C. (2000). Higher Education Demand in Spain: The Influence of Labour Market Signals and Family Background. Higher Education, 40, 147-162. http://dx.doi.org/10.1023/A:1004070925581

Blanden, J., \& Gregg, P. (2004). Family Income and Educational Attainment: A Review of Approaches and Evidence for Britain. Oxford Review of Economic Policy, 20, 245-263. http://dx.doi.org/10.1093/oxrep/grh014

Bourdieu, P. (1973). Cultural Reproduction and Social Reproduction. In R. Brown (Ed.), Knowledge, Education, and Cultural Change (pp. 71-84). London: Tavistock Publications.

Bourdieu, P., \& Passeron, J. (1977). Reproduction in Education, Society and Culture. SAGE Studies in Social and Educational Change, 5.

Bourdieu, P. (1986). The Forms of Capital. In G. R. Richardson (Ed.), Handbook of Theory and Research for the Sociology of Education (pp. 241-258). New York: Greenwood Press.

Checchi, D. (2006). The Economics of Education: Human Capital, Family Background. USA: Cambridge University Press. http://dx.doi.org/10.1017/CBO9780511492280

Currie, J., \& Moretti, E. (2003). Mother's Education and the Intergenerational Transmission of Human Capital: Evidence from College Openings. Quarterly Journal of Economics, 118, 1495-1532.

http://dx.doi.org/10.1162/003355303322552856

Denzler, S. (2011) Family Background Effects on the Choices of Higher Education Institution. Swiss Journal of Sociology, 37, 79-97.

Dika, S. L., \& Singh, K. (2002). Applications of Social Capital in Educational Literature: A Critical Synthesis. Review of

${ }^{7}$ Education funding's accounting for $4 \%$ of the GDP is a Chinese government 's policy objective, which was first proposed in China Education Reform and Development Program 1993). 
Educational Research, 72, 31-60. http://dx.doi.org/10.3102/00346543072001031

Fang, C. (2011). The Influence of Family Background on Individuals' Educational Attainment: An Analysis from the Perspective of Residential Differentiation. Journal of Educational Studies, 7, 118-226.

Fang, C., \& Feng, X. (2008). Family Background and Academic Achievement: A Study on the Social Stratum Differentiation in Compulsory Education. Zhejiang Social Sciences, 8, 47-55.

Gerardi, S. (2011). Family Income and Fathers' Education as a Function of Human Capital. International Journal of Academic Research, 3, 85-89.

Hou, L., Li, F., \& Zheng, Q. (2008). The Impact of Family Background on the Access to Quantity and Quality of Higher Education-From Social Stratification Perspective. Journal of Higher Education, 10, 39-45.

Krishnan, P. (1996). Family Background, Education and Employment in Urban Ethiopia. Oxford Bulletin of Economics \& Statistics, 58, 167-183. http://dx.doi.org/10.1111/j.1468-0084.1996.mp58001008.x

Lauglo J. (2011). Political Socialization in the Family and Young People’s Educational Achievement and Ambition. British Journal of Sociology of Education, 32, 53-74. http://dx.doi.org/10.1080/01425692.2011.527722

Onatsu-Arvilommi, T., \& Nurmi, J. (1997). Family Background and Problems at School and in Society: The Role of Family Composition, Emotional Atmosphere, and Parental Education. European Journal of Psychology of Education, 12, 315-330. http://dx.doi.org/10.1007/BF03172879

Shen, Z., \& Yan, F. (2006). The Impact of Social Stratification on Education Stratification: Empirical Analysis of Social and Economic Status of Students at Private Higher Education Institution in Xi'an City. Peking University Education Review, 4, 72-84.

Symeou, L. (2007). Culture Capital and Family Involvement in Children's Education: Tales from Two Primary Schools in Cyprus. British Journal of Sociology of Education, 28, 473-487. http://dx.doi.org/10.1080/01425690701369525

Tan, M., \& Xie, Z. (2011). Family Background, Ethnic Identity and Chinese Minorities’ Acquisition of Higher Education. Journal of Higher Education, 32, 50-58.

Tao, H., \& Yang, D. (2007). An Empirical Analysis of the Relationship between Educational Achievement and Family Background of High School Students. Tsinghua Journal of Education, 28, 29-33.

Tieben, N., Graaf, P., \& Graaf, N. (2010). Changing Effects of Family Background on Transitions to Secondary Education in the Netherlands: Consequences of Educational Expansion and Reform. Research in Social Stratification and Mobility, 28, 77-90. http://dx.doi.org/10.1016/j.rssm.2009.12.004

Van Eijck, K. (1996). Family and Opportunity: A Sibling Analysis of the Impact of Family Background on Education, Occupation and Consumption. The Netherlands: Tilburg University Press.

Wang, C. (2012). Study on the Relationship between Family Background, Self-Efficacy and Academic Attitude-Empirical Investigation with Students from Sino-Foreign Cooperative Education Programs. Higher Education Exploration, 6, 77-81.

Waters, J. L. (2006). Geographies of Cultural Capital: Education, International Migration and Family Strategies between Hong Kong and Canada. Transactions of the Institute of British Geographers, 31, 179-192. http://dx.doi.org/10.1111/j.1475-5661.2006.00202.x

Wei, J., Luo, P., \& Song, Y. (2009). On Family Background and Abandonment of College Access. Journal of Education Development, 21, 15-20.

Wen, D. (2005). The Impacts of SES on Higher Education Opportunity and Graduate Employment in China. Peking University Education Review, 3, 58-63.

Yang, D. (2012). Empirical Investigation with Family Background and the Equalization of Opportunities for Higher Education. Higher Education Exploration, 5, 140-143.

Yang, Q. (2011). The Impact of Family Background on Higher Education Opportunities. Modern Education Management, 7 , 22-24.

Yang, Q. (2012). Family Background with the Education of Different Levels, Qualities and Characters. Higher Education Exploration, 6, 144-148.

Zhang, Y. (2010). Family Background Affecting People’s Access to Education and Social Stratum Status. Journal of Graduate School Chinese Academy of Social Sciences, 4, 82-92.

Zhou, M., \& Kim, S. S. (2006). Community Forces, Social Capital and Educational Achievement: The Case of Supplementary Education in the Chinese and Korean Immigrant Communities. Harvard Educational Review, 76, 1-2. 
Scientific Research Publishing (SCIRP) is one of the largest Open Access journal publishers. It is currently publishing more than 200 open access, online, peer-reviewed journals covering a wide range of academic disciplines. SCIRP serves the worldwide academic communities and contributes to the progress and application of science with its publication.

Other selected journals from SCIRP are listed as below. Submit your manuscript to us via either submit@scirp.org or Online Submission Portal.
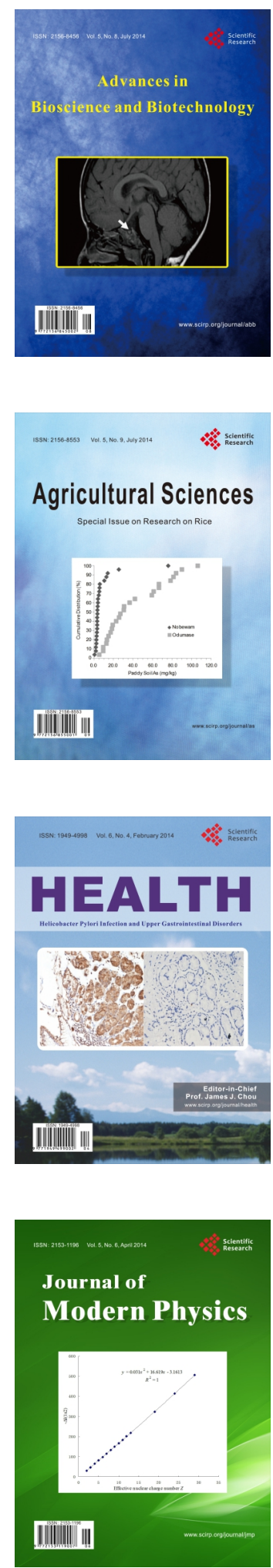
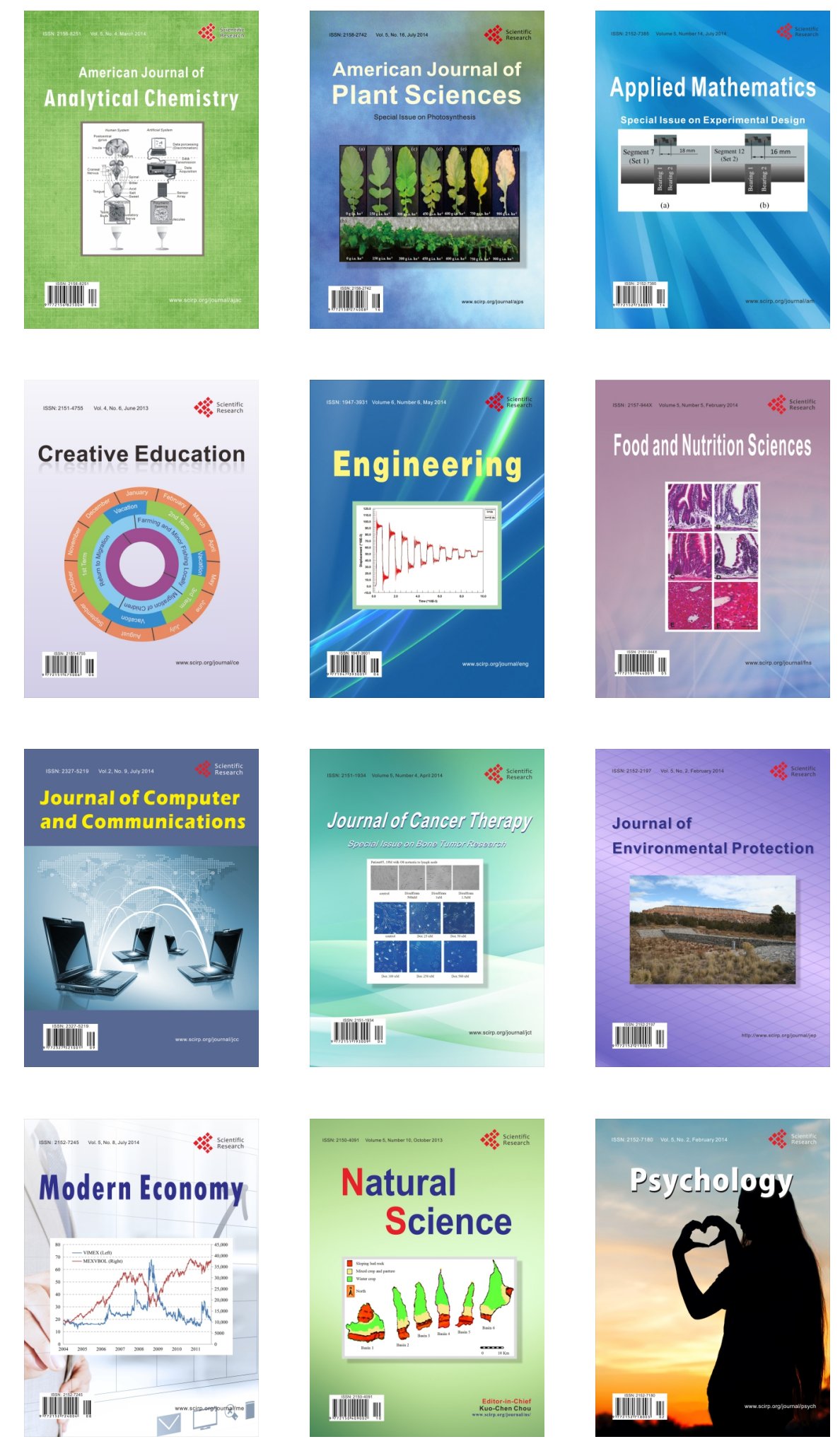